\title{
Modern extirpation of the Texas kangaroo rat, Dipodomys elator, in Oklahoma: changing land use and climate over a century of time as the road to eventual extinction
}

\author{
Janet K. Braun ${ }^{1 *}$, Brandi S. Coyner ${ }^{1}$, and Michael A. Mares ${ }^{1,2}$ \\ 1 Sam Noble Oklahoma Museum of Natural History, University of Oklahoma, 2401 Chautauqua Avenue, Norman, OK 73072 USA \\ Email: jkbraun@ou.edu (JKB), bcoyner@ou.edu (BSC). \\ 2Department of Biology, University of Oklahoma, Norman, OK 73092 USA. Email: mamares@ou.edu (MAM). \\ ${ }^{*}$ Corresponding author
}

\begin{abstract}
Surveys conducted during three years (2014-2017) provide the most extensive documentation to date for the possible presence of the Texas kangaroo rat (Dipodomys elator), a Tier II species considered to be of greatest conservation need, in seven counties in southwestern Oklahoma. The project encompassed 15 surveys on 93 nights; 266 localities were surveyed for a total of 9,094 trap nights and more than 32,428 $\mathrm{km}$ of paved and unpaved roads were surveyed for potential habitat and activity. No Texas kangaroo rats were captured or observed. However, 2,178 individuals of 17 mammal species were captured and individuals of 12 additional mammal species were collected and/or observed. New locality and natural history information for mammal species was obtained and six county records were recorded based on specimens and/ or observations. Project results and historical information suggest that the Texas kangaroo rat (D. elator) is likely extirpated from the state of Oklahoma.

Estudios conducidos en Oklahoma durante tres años (2014-2017) proveen los datos extensivos de la posible presencia de la Texas kangaroo rat (Dipodomys elator), una especie considerado como Tier II que requiere la máxima atención para conservación en siete condados del suroeste de Oklahoma. El estudio incluyó 15 muestreos por 93 noches; 266 localidades distintas fueron muestreados con 9,094 trampa-noches y más de 32,428 km de caminos pavimentados y de tierra fueron examinados para el hábitat y actividad potencialmente. Ningún ejemplar de D. elator fue visto o capturado. Sin embargo, 2,178 individuos de 17 especies de mamíferos fueron colectados o observados. Nuevas localidad e información de la historia natural de las especies fue obtenida, se registran datos ejemplares o observaciones para seis condados. Los resultados de este estudio y datos históricos sugieren que el Texas kangaroo rat ( $D$. elator) fue extirpado del estado de Oklahoma.
\end{abstract}

Keywords: Dipodomys elator; extinction; land use; Oklahoma; Texas kangaroo rat.

๑) 2021 Asociación Mexicana de Mastozoología, www.mastozoologiamexicana.org

\section{Introduction}

Human activities during the last century have affected the distribution of mammal species throughout the world (Ceballos et al. 2017; Ceballos et al. 2020). Occasionally these impacts are shown through major geographic range restrictions of megafauna, such as elephants or tigers and other predators (Ceballos et al. 2017; Ceballos et al. 2020). Certainly, these are charismatic species for conservation groups or for governments seeking to preserve high profile fauna, though being a high-profile animal may prove problematic for conservation (see Courchamp et al. 2018). Research on small mammals in danger of extinction due to habitat and climate change is less common. When a new genus and species of small salt-dwelling rodent (Pipanacoctomys aureus) was discovered in an isolated valley in northwestern Argentina, both climate change and habitat effects were hypothesized to greatly limit the species and eventually to affect its viability in the salt desert (Mares et al. 2000). Other small mammal studies also have implicated climate and land use in rarefaction of species (Cameron and Scheel 2001).

The Texas kangaroo rat, Dipodomys elator, is a geographically limited small mammal that has been documented in southern Oklahoma and adjacent Texas. This species was described in 1894 from Henrietta, Clay County, Texas (Merriam 1894). It was reported for Oklahoma in the early $1900 \mathrm{~s}$ when two specimens were collected in November 1904 and July 1905 in southwestern Oklahoma near Chattanooga, Comanche County (Bailey 1905). Bailey (1905:149) reported that "while not numerous, they seem to be well distributed in the vicinity" and were found or known to be living under houses and outbuildings and feeding on Kafir corn (a predecessor of milo and grain sorghums). Despite its putative ubiquity, this species was only known for Oklahoma from these two specimens, until a specimen was collected in 1969 immediately north of the Red River in Cotton County in association with Ord's kangaroo rat, Dipodomys ordii (Baumgardner 1987).

Previous researchers (e. g., Baumgardner 1987; Moss and Mehlhop-Cifelli 1990; Stangl et al. 1992) have suggested that the Texas kangaroo rat has been extirpated from Oklahoma. However, only modest efforts had been made to determine its presence in the state. For example, road surveys were conducted two nights in 1970 (Martin and Matocha 1972), road surveys totaling $637 \mathrm{~km}$ were made in Comanche (99.6 km), Tillman (119.7 km), and Cotton $(417.9 \mathrm{~km})$ counties between 1985 and 1987 (Jones et al. 1988), and an undetermined amount of sampling was conducted by personnel of Midwestern State University in the area where the specimen was reported from Cotton County (Baumgardner 1987). During summer 1988, a 
survey conducted by Moss and Mehlhop-Cifelli (1990) consisted of 354 trap nights, $66 \mathrm{~km}$ of night road surveys, and the examination of aerial photographs and soil maps to determine potential habitat. Martin (2002) reported conducting road surveys during June to August from 1996 to 2000 in 12 Texas and two Oklahoma counties; however, no data are presented in the report for the Oklahoma counties.

In contrast, records of $D$. elator have been reported from localities in 11 counties in northern Texas (Archer, Baylor, Childress, Clay, Cottle, Foard, Hardeman, Montague, Motley, Wichita, and Wilbarger); an additional Texas county record (Coryell) is unverified (Dalquest and Collier 1964; Packard and Judd 1968; Martin and Matocha 1972, 1991; Cokendolpher et al. 1979; Baumgardner 1987; Jones et al. 1988; Martin 2002). Extensive research has been conducted in some of these counties to better understand the distribution, ecology, diet, behavior, reproduction, natural history, and genetic diversity of the Texas kangaroo rat (e. g., Dalquest and Collier 1964; Chapman 1972; Martin and Matocha 1972, 1991; Packard and Roberts 1973; Roberts and Packard 1973; Webster and Jones 1985; Jones et al. 1988; Stangl and Schafer 1990; Stangl et al. 1992, 2005; Goetze et al. 2007, 2008; Nelson et al. 2009, 2013; Stasey et al. 2010; Nelson and Goetze 2013; Goetze et al. 2015; Pfau et al. 2019). These data constitute the majority of the knowledge of the biology of the Texas kangaroo rat.

In 1996, the International Union for Conservation of Nature (IUCN) listed D. elator as vulnerable based on its decline throughout its historic range (Wahle et al. 2018). Habitat degradation, fragmentation, and loss of habitat from conversion to agricultural uses and development were cited by the IUCN as major threats. Although the species was listed as a category two candidate species by the United States Fish and Wildlife Service (USFWS) in 1982 (47 FR 58454), the practice of maintaining a category two candidate list was discontinued in 1996 (61 FR 64481). In Texas, D. elator was listed as a threatened protected nongame species in 1977 (Texas 1977), a threatened non-game species in 1985 (Texas 1985), and as a threatened species in 1987 (Texas 1987). In Oklahoma, D. elator was identified as a Tier II species of greatest conservation need by the Oklahoma Department of Wildlife Conservation (Appendix E, Oklahoma Comprehensive Wildlife Conservation Strategy 2016). In 2010, WildEarth Guardians petitioned the USFWS to federally list the Texas kangaroo rat (WildEarth Guardians 2010). In 2011, the USFWS determined that "the petition presents substantial scientific or commercial information indicating that listing the Texas kangaroo rat throughout its entire range may be warranted" and a status review was initiated (FWS-R2-ES-2011-0011; USFWS 2011).

To evaluate the status of this species of greatest conservation need in Oklahoma and to develop and implement scientifically sound management and conservation initiatives if its presence was documented, information was needed by the Oklahoma Department of Wildlife Conservation. Thus, the purpose of this study was to address a criti- cal and immediate need by assessing the presence, distribution, and habitat of the Texas kangaroo rat to determine its status in the State of Oklahoma where it was little known and presumed extirpated.

\section{Materials and Methods}

Observation and trapping surveys were conducted in seven counties in southwestern Oklahoma, including Harmon, Jackson, Tillman, Cotton, Greer, Kiowa, and Comanche from 1 October 2014 to 30 September 2017 (Figure 1). These counties were selected based on their proximity to areas in Texas where $D$. elator is or was known to occur and because two of them are the reference sites for the only known specimens from Oklahoma. Localities that were accessible (e. g., roadsides, private land where permission was secured, parks, state and city property), one historic site (Bailey 1905), and one recent site (Baumgardner 1987) were surveyed for the presence of burrows and activity of the Texas kangaroo rat. Surveys also were conducted along paved and unpaved roads and by walking potential habitat.

Dipodomys elator is not reported to hibernate and is active year-round (Dalquest and Collier 1964); thus, the survey and inventory approach included surveys during all seasons. Localities surveyed were selected based primarily on soil and vegetation preferences described for $D$. elator in Texas (Martin 2002; Nelson et al. 2013). Texas kangaroo rats have been reported to inhabit arid areas not prone to flooding (Martin 2002), characterized by short, sparse grasses (Goetze et al. 2007; Nelson et al. 2009), and containing little woody canopy cover (Goetze et al. 2007). Although they have been reported to occur only in localities where the soil contains a significant clay component (Bailey 1905; Dalquest and Collier 1964; Roberts and Packard 1973; Martin and Matocha 1991), they are not restricted to such soils (Martin and Matocha 1991).

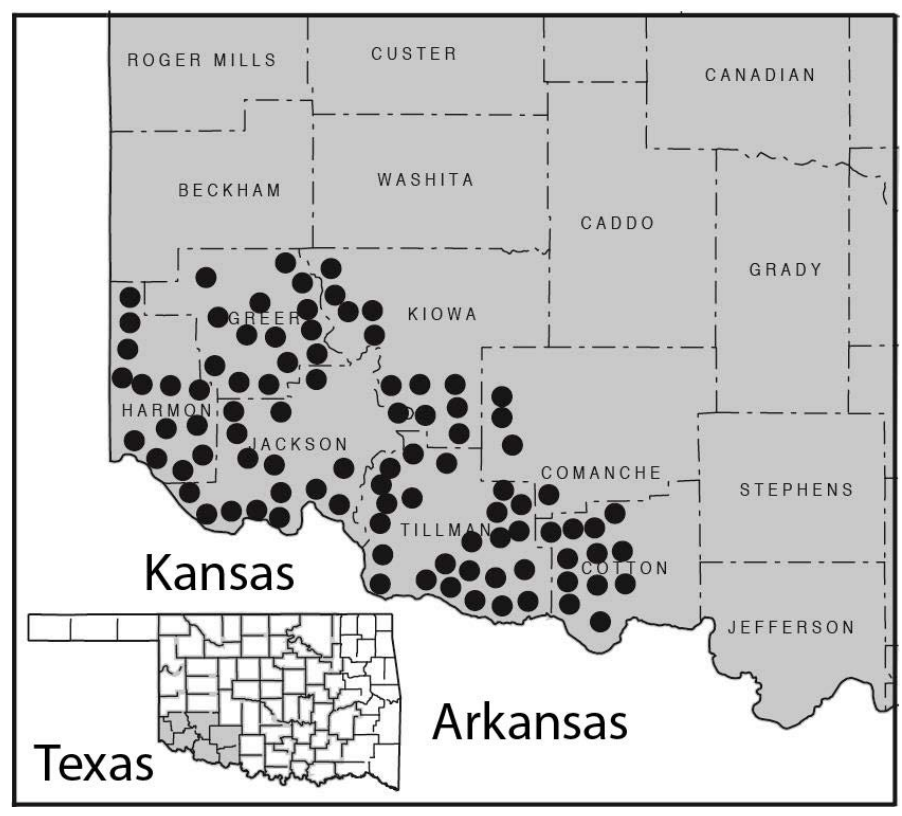

Figure 1. Map of 266 localities surveyed for D. elator in southwestern Oklahoma. Dots may represent more than one locality. 
Localities were examined for the presence of burrows, distinct trails, and dust-bathing areas. Trapping to test for burrow occupancy was conducted by placing $7.5 \times 8.8 \times 30$ $\mathrm{cm}$ folding Sherman Live Traps (extended length to minimize damage to tails) within 0.10 to $0.50 \mathrm{~m}$ of each burrow entrance, with the open end of each trap facing the burrow entrance. If no burrows were present, traps were placed in survey lines. Traps were baited with oatmeal each evening and checked each morning.

Small mammal species that were captured were released or euthanized, prepared as scientific voucher specimens including tissue samples, and deposited in the Collection of Mammals and Oklahoma Collection of Genomic Resources at the Sam Noble Oklahoma Museum of Natural History, respectively. All protocols followed guidelines described by Sikes et al. $(2011,2016)$ for the use of wild mammals in research and were approved by the University of Oklahoma Institutional Care and Use Committee (R13-010, R16-011).

Because Ord's kangaroo rat $(D$. ordii) also is known to occur in the seven counties that were surveyed, all individuals of Dipodomys that were captured were carefully identified. Dipodomys elator and $D$. ordii are easily distinguished from each other using external characteristics. The Texas kangaroo rat has a white-tipped tail and four toes on the hind feet, whereas the tail seldom is white-tipped in Ord's kangaroo rat and the hind feet have five toes (Carter et al. 1985; Caire et al. 1989).

Specific methods and procedures were developed should D. elator be captured or observed. For burrows, the diameter and orientation of entrance/exit hole would be recorded (see Figure 3 in Stangl et al. 1992) and the specific location of each burrow recorded in decimal degrees using a GPS unit, set to WGS84 datum. For captures, individuals of $D$. elator would be photographed, sexed, checked for reproductive condition, relative age and condition, and marked with hair dye in order to determine recapture rates. A small ear biopsy would be taken to provide a small tissue sample for genetic studies. Contents of check pouches would be extracted and analyzed to determine diet. The site of each capture would be recorded using a GPS and the animals released at the point of capture. Soil and vegetation would be sampled at each site and analyzed. The habitat would be photographed and described in general terms; the capture or sighting site also would be described according to its association in the landscape. A $1 \mathrm{~m}^{2}$ quadrat would be placed directly over burrows or the capture location. Within each quadrat, vegetative richness would be recorded as the total number of species present. Percentage cover of grass, forbs, bare ground, woody vegetation, and rocks would be recorded. Average herbaceous vegetation height would be obtained by averaging the height of the herbaceous vegetation $15 \mathrm{~cm}$ interior to each corner of the quadrat. The height of woody vegetation also would be recorded as the height of the lowest branch. Specimens of dominant plants would be collected, placed in a plant press, and deposited as voucher specimens. Vegetation and soil data between quadrats would be analyzed and compared.

\section{Results}

Fifteen surveys were conducted from 2014 to 2017 to document the presence (or absence) of the Texas kangaroo rat (D. elator) in seven counties in southwestern Oklahoma. Surveys were conducted during a total of 93 nights in October 2014 (10 nights), February 2015 (7 nights), May 2015 (4 nights), July 2015 (6 nights), August 2015 (5 nights), April 2016 (7 nights), May 2016 (7 nights), June 2016 (6 nights), July 2016 (7 nights), August 2016 (5 nights), September 2016 (3 nights), May 2017 (7 nights), June 2017 (7 nights), July 2017 (7 nights), and August 2017 (5 nights). A total of 266 localities was surveyed (Table 1; Figure 1), with the total number of localities for each county varying from 7 (Comanche) to 83 (Tillman). Although fewer localities were surveyed in Year 1 (84), 91 localities were surveyed in both Year 2 and Year 3.

A total of 9,094 trap nights (a trap night is equal to one trap set for one night) of effort was achieved during the three-year project (Year 1: 2,302; Year 2: 3,022; Year 3: $3,770)$. This effort is about 25.7 times the effort of the previous survey by Moss and Mehlhop-Cifelli (1990; 354 trap nights). Trap success for all small mammals varied from 0 to $100 \%$, but averaged $24.6 \%$ across all sites ( 25.04 Year 1 ; $33.86 \%$ Year 2; $9.76 \%$ Year 3).

Visual surveys also were conducted along roads for large portions of each of the seven counties. Habitats along more than $32,428 \mathrm{~km}$ of paved and unpaved roads were surveyed for the presence of potential $D$. elator habitat, burrows, and activity: 11,265 km for Year 1; 11,265 km for Year 2; 9,898 km for Year 3. This effort is estimated at more than 43.6 times the efforts from previous surveys (Martin and Matocha 1972; Jones et al. 1988; Moss and Mehlhop-Cifelli 1990).

No D. elator was captured or observed in Years 1, 2, or 3. However, 2,178 individuals of 17 mammal species were captured (Table 2). Of these, 563 were prepared as scientific voucher specimens including tissue samples and deposited in the Collection of Mammals and Oklahoma Collection of Genomic Resources at the Sam Noble Oklahoma Museum of Natural History, respectively. The remaining 1,617 individuals of the 2,178 individuals captured were identified and released. Although no D. elator was captured or observed, this project provides new locality and natural history information on 30 other mammal species in seven counties in southwestern Oklahoma, including six new county records (Braun et al. 2020; Braun et al. pers. observ.). This information continues to expand the knowledge of mammal species throughout the state.

\section{Discussion}

The known historical distribution of the Texas kangaroo rat is limited to two localities in two counties in southwestern Oklahoma and localities in 11 counties in northern Texas; as noted previously, an additional Texas county record (Coryell) is unverified (Dalquest and Collier 1964; Packard and Judd 1968; Martin and Matocha 1972; Cokendolpher 


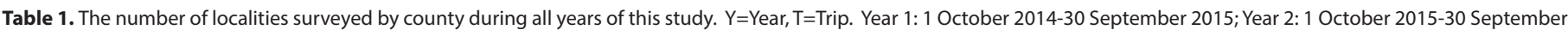
2016; Year 3: 1 October 2016-30 September 2017.

\begin{tabular}{|c|c|c|c|c|c|c|c|c|}
\hline \multirow[t]{2}{*}{ YearTrip } & \multicolumn{7}{|c|}{ County } & \multirow[t]{2}{*}{ Total } \\
\hline & Comanche & Cotton & Greer & Harmon & Jackson & Kiowa & Tillman & \\
\hline Y1T1 & & & & 5 & 18 & & & 23 \\
\hline Y1T2 & & 8 & & & & & 12 & 20 \\
\hline Y1T3 & & & & & & & 9 & 9 \\
\hline Y1T4 & & & 10 & & & 8 & & 18 \\
\hline Y1T5 & 3 & & & & & 6 & 5 & 14 \\
\hline Total Y1 & 3 & 8 & 10 & 5 & 18 & 14 & 26 & 84 \\
\hline Y2T1 & & & 7 & 4 & 7 & & 2 & 20 \\
\hline Y2T2 & & & 1 & 7 & 7 & & & 15 \\
\hline Y2T3 & & 4 & & & & & 8 & 12 \\
\hline Y2T4 & & & 12 & & 7 & & 3 & 22 \\
\hline Y2T5 & 3 & 4 & & & & 2 & 4 & 13 \\
\hline Y2T6 & & 9 & & & & & & 9 \\
\hline Total Y2 & 3 & 17 & 20 & 11 & 21 & 2 & 17 & 91 \\
\hline Y3T1 & & & 8 & 8 & 2 & & 3 & 21 \\
\hline Y3T2 & & & & 7 & 7 & & 11 & 25 \\
\hline Y3T3 & & 18 & & & & & 6 & 24 \\
\hline Y3T4 & 1 & & & & & & 20 & 21 \\
\hline Total Y3 & 1 & 18 & 8 & 15 & 9 & & 40 & 91 \\
\hline Grand Total & 7 & 43 & 38 & 31 & 48 & 16 & 83 & 266 \\
\hline
\end{tabular}

et al. 1979; Martin and Matocha 1991; Martin 2002). This geographic region encompassed arid areas of short or overgrazed grass with open areas of bare ground and clay or sandy loam soils, such as mesquite-buffalo grass pastures, which research indicates is the preferred habitat of $D$. elator (Dalquest and Collier 1964; Stangl et al. 1992; Goetze et al. 2007; Nelson et al. 2009). However, research also suggests that the species may be somewhat opportunistic in its habitat requirements and have broader habitat tolerance than generally supposed (Stangl et al. 1992; Martin 2002).

Over nearly 125 years, much of the suitable habitat in the historic range of $D$. elator has been destroyed or modified (Stangl et al. 1992; Nelson et al. 2009). Key factors that have contributed to changes in the suitable habitat for $D$. elator include habitat degradation, fragmentation, habitat loss from conversion to agriculture, fire suppression, the disappearance of bison, decreased grazing, and loss of historical ecological processes (Figure 2; Stangl et al. 1992; Nelson et al. 2009; Holt 2018). In 1988 in Oklahoma, Moss and Mehlhop-Cifelli (1990) found only $2.6 \%$ of the total area surveyed consisted of potential Texas kangaroo rat habitat and at many sites no suitable habitat was found after an initial identification using aerial photographs and soil survey maps. Between 1985 and 2000 in Texas, significant changes in the habitat in the historic range of $D$. elator were found to correspond to an increase in Conservation Reserve Program fields that resulted in increasing the density and coverage of grasses, an increase in cultivated areas, and a transition to monocultures (Martin 2002). Martin (2002) noted that, in Texas, the "habitat in much of the historic range of the species is not suitable to maintain viable populations." By 2002 in Texas, Martin (2002) suggested that Texas kangaroo rats were present in only five of the 11 counties where it previously had been reported. During the 2014 to 2017 study reported herein, surveys of 266 sites and observations along more than $32,428 \mathrm{~km}$ of paved and unpaved roads in Oklahoma found no individuals and few areas of what might be considered suitable habitat for $D$. elator.

Although there is little information on the historical distribution of $D$. elator in Oklahoma, it may have overlapped or coincided with the area known as the Big Pasture (Figure 3), located in what is now parts of Comanche, Cotton, and Tillman counties (Cooper 1957). The surplus lands of the Apache, Comanche, and Kiowa nations were opened to white settlement by lottery from 9 July to 6 August 1901, but the 488,000acre Big Pasture was set aside for grazing reserves of the Apache, Comanche, and Kiowa nations. In December 1906, however, the Big Pasture, the last large tract of land unavailable for white settlement in Oklahoma Territory, was opened by sealed bids (Cooper 1957). The Big Pasture had been grazed by bison herds and supported wolves recently enough for Theodore Roosevelt to hunt them there (Wynn 2011).

The impact of opening this area to settlement cannot be overstated. Within a year of opening of Big Pasture in 1906, 2,337 families had settled the area (Cooper 1957). Even before the opening of the Apache, Comanche, and Kiowa lands in 1901, the Big Pasture had been leased to Texas ranchers for grazing and quarter sections were leased for agriculture. Stipulations in agricultural leases included 


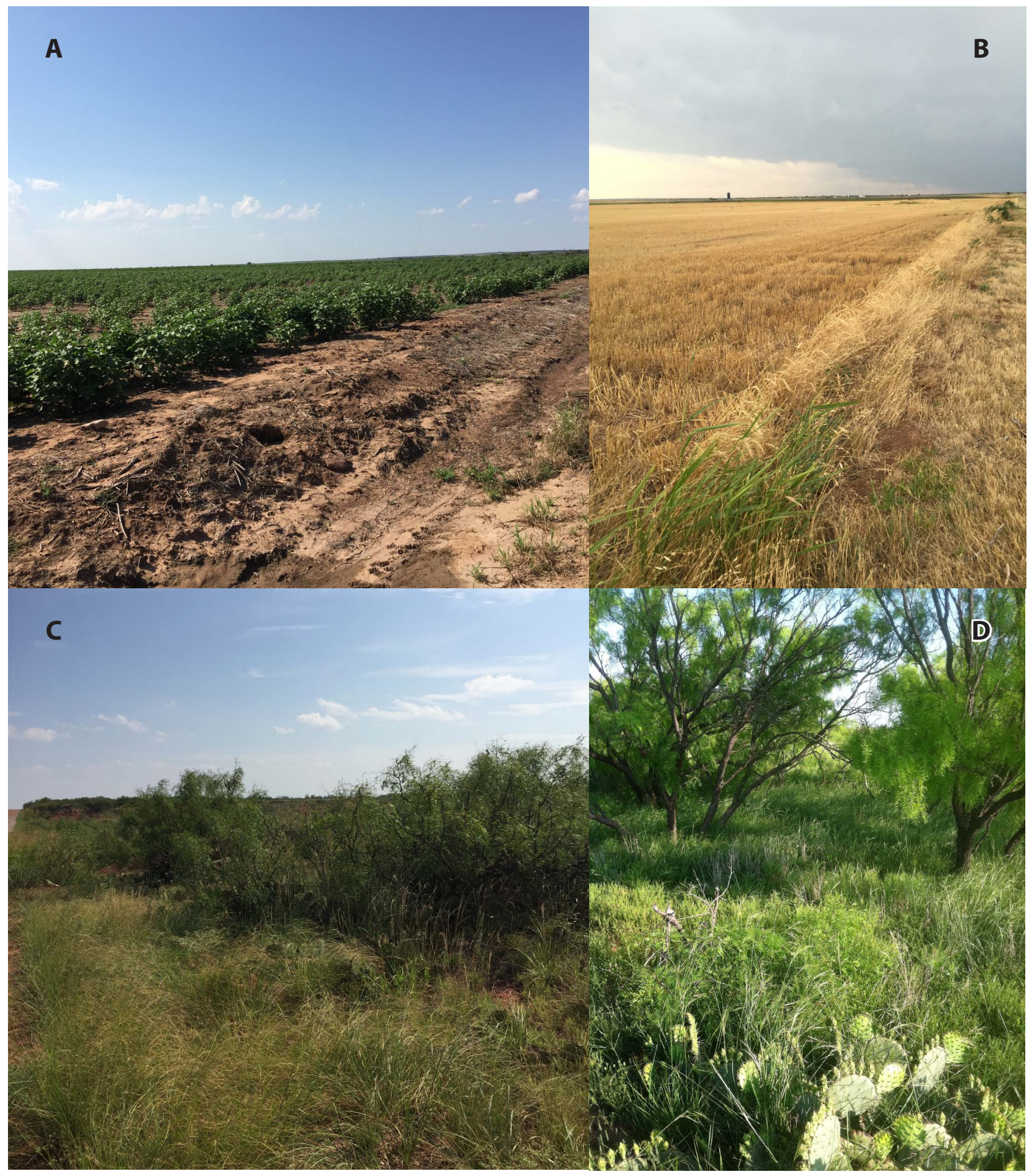

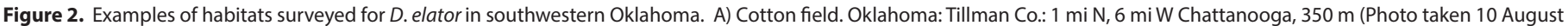

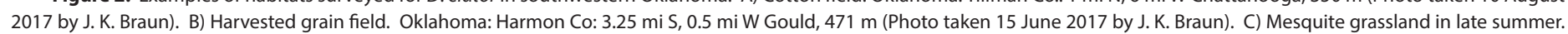

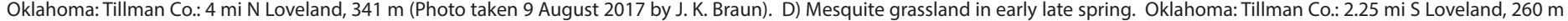
(Photo taken 4 May 2015 by J. K. Braun).

the provisions that at least 120 acres had to be "broken out" and quarter sections fenced with a four-wire fence. Agriculture developed very rapidly in the Big Pasture (e. g., cotton, wheat, sorghum, and milo) as well as statewide. Between 1890 and 1900, the number of farms in Oklahoma increased from 8,826 to 108,000 and to 190,192 by 1910 , making Oklahoma one of the most rapidly settled agricultural frontiers in the history of the United States (Fite 2009). Habitat conversion has been shown to have major effects on many wildlife species (Sykes et al. 2019). 
Habitat suitable for D. elator in Oklahoma was likely fragmented due to the rapid conversion of native habitat to agricultural use and agricultural practices that became more intensive over time. In 1910, 80 to $95 \%$ of the acres in these seven counties were in farms and the percent acres in cultivation ranged from $34 \%$ to $41 \%$. The trend toward habitat conversion continues today as the percent land in farms (cropland and pastureland), excluding Comanche County, increased an average of $7.5 \%$ (1-17\%) from 2007 to 2012. Presently, the percent of acres in farms in 2012 for six of the seven counties that were surveyed ranged from 91 to $99 \%$ (2012 USDA Census of Agriculture); Comanche County had $68 \%$ in farms, a number lower likely due to the presence of a large military installation and a national wildlife refuge.

Although some small mammals may utilize the interiors of agricultural fields, D. elator generally avoids them because deep plowing disturbs or destroys animals and their burrow systems (Martin and Matocha 1972; Martin 2002). In Texas, D. elator may, however, inhabit the undisturbed edges and road banks bordering pastures or cultivated fields (Martin 2002; Goetze et al. 2016). However, unlike Texas, most areas in southwestern Oklahoma are cultivated from section line to section line or have roadsides covered with dense areas of native and non-native grasses (Figure 2). Thus, even edges and road banks, which are used by $D$. elator in Texas-and may have been used historically in Oklahoma-disappeared or became narrower over time with expanded plowing as well as from the activities of blading and road construction.

Grazing and associated disturbances also have been suggested as important factors in maintaining suitable habitat for D. elator (Stangl et al. 1992; Stasey 2005; Goetze et al. 2007). But, changes in grazing practices and control of wildfires also have resulted in modifications in suitable habitat for D. elator (Diamond and Shaw 1990). Many uncultivated fragments that were fenced and grazed by cattle are no longer intensively grazed, resulting in an increased abundance of mesquite, shrubs, grasses, and forbs, the invasion of introduced plant species, and a decrease in the presence of bare ground (Diamond and Shaw 1990; Stangl et al. 1992; Martin 2002; Stasey 2005; Goetze et al. 2007; Nelson et al. 2009; Stasey et al. 2010). The control of wildfires has allowed the increase of woody vegetation (specifically mesquite) that, as it matures, increases the amount of shade and changes the composition of the vegetation, often in favor of dense introduced grasses (Nelson et al. 2009). Uncultivated lands allowed to attain a mature mesquite stage do not provide preferred or historical habitat for D. elator (Goetze et al. 2007; Stasey 2005). In addition, extensive modification of mesquite pastures through mesquite eradication or reduction has been shown to reduce available suitable habitat (Lewis 1970; Martin and Matocha 1972).

Several small mammal species known to be associated with $D$. elator were captured during this project. These include: Ictidomys tridecemlineatus, Chaetodipus hispidus, Perognathus merriami, Peromyscus leucopus, Peromyscus maniculatus cf P. sonoriensis (Bradley et al. 2019), Reithrodontomys sp., and Neotoma micropus (Roberts and Packard 1973; Stangl et al. 1992; Martin 2002; Goetze et al. 2007; Stasey et al. 2010). But, the largest numbers of captures were that of $S$. hispidus (1,200 of 2,178 captures), a species with which D. elator rarely co-occurs and, indeed, actively avoids (Chapman 1972; Goetze et al. 2007; Packard and Roberts 1973; Rob-

Table 2. Mammal species and total individuals captured for seven counties surveyed during all years, 2014-2017.

\begin{tabular}{|c|c|c|c|c|c|c|c|c|}
\hline \multirow[t]{2}{*}{ Species } & \multicolumn{7}{|c|}{ County } & \multirow[t]{2}{*}{ Total } \\
\hline & Comanche & Cotton & Greer & Harmon & Jackson & Kiowa & Tillman & \\
\hline Didelphis virginiana & & & & & & 1 & 1 & 2 \\
\hline Sylvilagus floridanus & & 1 & 1 & & & & & 2 \\
\hline Ictidomys tridecemlineatus & & 1 & & 1 & & & 1 & 3 \\
\hline Xerospermophilus spilosoma & & & & & & & 2 & 2 \\
\hline Perognathus merriami & & & 3 & 1 & 20 & & & 24 \\
\hline Chaetodipus hispidus & 9 & 28 & 23 & 28 & 81 & 10 & 32 & 211 \\
\hline Dipodomys ordii & & 7 & 36 & 41 & 30 & 1 & 38 & 153 \\
\hline Reithrodontomys fulvescens & & & 3 & & & & & 3 \\
\hline Reithrodontomys montanus & & & 3 & & & & 1 & 4 \\
\hline Peromyscus leucopus & & 23 & 27 & 15 & 20 & 7 & 42 & 134 \\
\hline Peromyscus maniculatus cf $P$. sonoriensis & 3 & 36 & 18 & 6 & 16 & 5 & 101 & 185 \\
\hline Baiomys taylori & & & & & 1 & & & 1 \\
\hline Onychomys leucogaster & & & 19 & 9 & 5 & 4 & 14 & 51 \\
\hline Sigmodon hispidus & 45 & 608 & 83 & 40 & 163 & 89 & 172 & 1,200 \\
\hline Neotoma floridana & & 12 & & & & & 6 & 18 \\
\hline Neotoma micropus & 2 & & 36 & 30 & 85 & 15 & 9 & 177 \\
\hline Mus musculus & & & & 1 & 3 & 3 & 1 & 8 \\
\hline
\end{tabular}




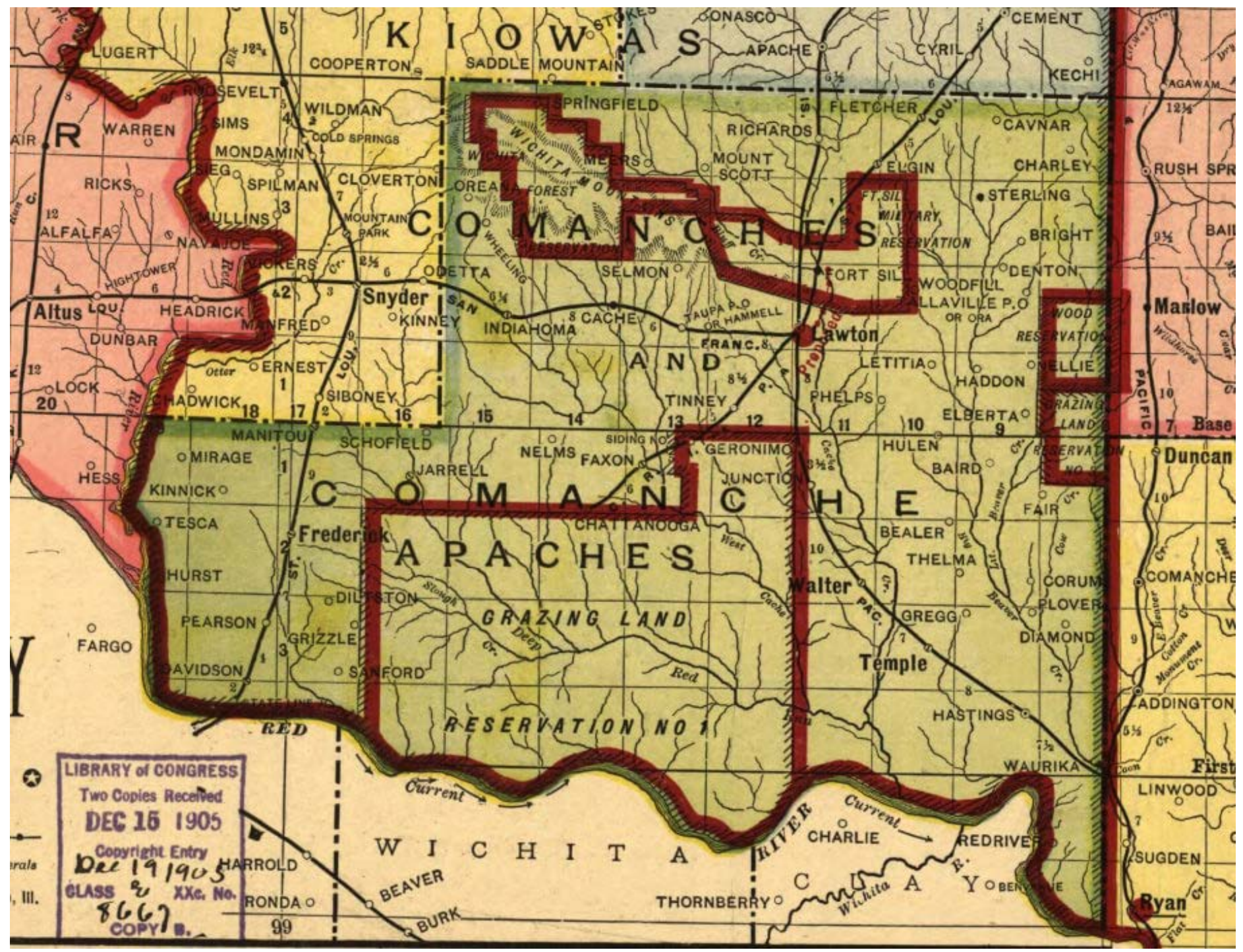

Figure 3. Map of the Big Pasture (labeled as Grazing Land Reservation No. 1) from the Library of Congress and published in The Daily Oklahoman in 1905.

erts and Packard 1973; Stasey et al. 2010). That S. hispidus was such a commonly captured species may be a reflection of changes in grazing practices and control of wildfires. The cotton rat, Sigmodon hispidus, has increased both its population density and geographic range with changing grazing practices over many decades (Slabach and Krupa 2018). Indeed, climate change has been implicated in cotton rat populations in recent years, with species range expansions expected over the coming decades (https://www.fs.fed.us/ rmrs/sites/default/files/documents/Sigmodon\%20hispidus\%20Species\%20Report.pdf). The projections for cotton rat expansion suggest that $D$. elator will not be expected to recolonize Oklahoma in the near future.

Other factors that may have altered the distribution of D. elator include the elimination of two mammal species (Bison bison and Cynomys ludovicianus) that significantly impact the environment and are known to create and maintain a disturbed, altered habitat preferred by D. elator (Stangl et al. 1992). The elimination of prairie dog mounds and other naturally occurring habitat heterogeneity features during the transition to agriculture also may have reduced the distribution of D. elator (Goetze et al. 2007).

The discovery of D. elator in Oklahoma in 1904 and 1905, and then a complete lack of records thereafter (with a single exception) corresponds directly to these major events in Oklahoma history. The capture of the two specimens from Chattanooga, Oklahoma (Savage, www.okhistory. org), which were not captured in native habitat, but in an area converted to agriculture (Kafir corn) and human habitation, represent a pivotal moment in the conservation history of this species. The rapid rate of human agricultural activities, habitat degradation, fragmentation, conversion of habitat, suppression of fire, and decreased grazing likely had an immediate impact on any populations of this habitat specialist in the state.

The results of this 3-year project provide the most extensive documentation of the absence of populations of D. elator in Oklahoma, particularly relative to its known historical locations, since 1988 (Moss and Mehlhop-Cifelli 1990). Although, more recently, Martin (2002) reported conducting road surveys during June to August from 1996 to 2000, no data for Oklahoma were presented in the report. In 
Oklahoma, this Tier II species is of greatest conservation need, with a low population status and an unknown population trend. It has been petitioned for potential listing as an endangered or threatened species under the United States Endangered Species Act. These results and historical information suggest that the Texas kangaroo rat (D. elator) has been extirpated from Oklahoma, but these results will be useful to the State of Oklahoma and USFWS in making decisions about the status of this species and will provide scientific data for the basis for the development and implementation of scientifically sound conservation measures and management strategies in areas where populations are present, such as Texas.

The earliest reports of $D$. elator in Oklahoma report the species as not common, but not threatened with extirpation either. However, the changing social adjustments of Oklahoma land allotments, conversion of habitats due to land use practices, massive changes engendered by grazing and other farm management practices, and climate change have led to the extirpation of this species from Oklahoma and a very unlikely prognosis for its return in the foreseeable future.

\section{Acknowledgments}

This paper honors Dr. David J. Schmidly for a lifetime's work on mammal research in the United States and Mexico. He published books on Texas mammals, reviewed the life of Vernon Bailey, and co-edited a volume of South American mammalogy. He also published more than 100 papers on mammal systematics, biogeography, conservation, and natural history. As president of several major universities, he was a tireless supporter of mammal research, collections, and museums. We thank the following individuals who aided in the field work; we appreciate greatly their assistance and they are remembered fondly: A. Allen, A. Ciarlante, E. Ellsworth, R. Estrada, D. Glidewell, B. Narr, and C. Zhou. We also thank the individuals that allowed access to their private property. This material is based upon work supported by a grant from the State Wildlife Grants Program, Oklahoma Department of Wildlife Conservation (F14AF01224 (T-78-1). Additional support was provided by the Sam Noble Oklahoma Museum of Natural History, University of Oklahoma. Any opinions, findings, and conclusions or recommendations expressed in this material are those of the authors and do not necessarily reflect the views of the Oklahoma Department of Wildlife Conservation.

\section{Literature cited}

Balley, V. 1905. Biological survey of Texas. North American Fauna 25:1-222.

Baumgardner, G. D. 1987. A recent specimen of the Texas kangaroo rat, Dipodomys elator (Heteromyidae), from Oklahoma. Southwestern Naturalist 32:285-286.

Bradley, R. D., J. Q. Francis, R. N. Platt II, T. J. Soniat, D. AlVAREZ, AND L. L. LINDSEY. 2019. Mitochondrial DNA sequence data indicate evidence for multiple species within Peromys- cus maniculatus. Special Publications, Museum of Texas Tech University 70:1-59.

Braun, J. K., M. A. Mares, B. S. Coyner, and L. S. Loucks. 2020. New records of mammals from Oklahoma. Occasional Papers, Museum of Texas Tech University 364:1-23.

Caire, W., J. D. Tyler, B. P. Glass, and M. A. Mares. 1989. Mammals of Oklahoma. University of Oklahoma Press, Norman.

Cameron, G, and D. Scheel. 2001. Getting warmer: effect of global climate change on distribution of rodents in Texas. Journal of Mammalogy 82:652-680.

Carter, D. C., W. D. Webster, J. K. Jones, JR., C. Jones, and R. D. Sutrkus. 1985. Dipodomys elator. Mammalian Species 232:1-3. Ceballos, G., P. R. Ehrlich, and R. Dirzo. 2017. Biological annihilation via the ongoing sixth mass extinction signaled by vertebrate population losses and declines. Proceedings of the National Academy of Sciences USA 114:E6089-E6096.

Ceballos, G., P. R. Ehrlich, and P. H. Raven. 2020. Vertebrates on the brink as indicators of biological annihilation and the sixth mass extinction. Proceedings of the National Academy of Sciences USA 117:13596-13602.

Chapman, B. 1972. Food habits of Loring's kangaroo rat, Dipodomys elator. Journal of Mammalogy 53:877-880.

Cokendolpher, J. C., D. L. Holub, and D. C. Parmley. 1979. Additional records of mammals from north-central Texas. Southwestern Naturalist 24:376-377.

Cooper, C. M. 1957. The Big Pasture. Chronicles of Oklahoma 35:138-146.

Courchamp, F., I. Jaric, C. Albert, Y. Meinard, W. J. Ripple, and G. Chapron. 2018. The paradoxical extinction of the most charismatic animals. Plos Biology https://doi.org/10.1371/journal.pbio.2003997.

Dalquest, W. W., AND G. Collier. 1964. Notes on Dipodomys elator, a rare kangaroo rat. Southwestern Naturalist 9:146-150.

Diamond, D. D., AND D. M. SHaw. 1990. GIS and remote sensing for Texas kangaroo rat habitat characterization. Unpublished final report prepared for Texas Parks and Wildlife Department. Austin, U.S.A.

FITE, G. C. 2009. Farming. The Encyclopedia of Oklahoma History and Culture, www.okhistory.org (accessed 30 October 2017).

Goetze, J. R., A. D. Nelson, and C. Stasey. 2008. Notes on behavior of the Texas kangaroo rat (Dipodomys elator). Texas Journal of Science 60:309-316.

Goetze, J. R., W. C. Stasey, A. D. Nelson, and P. D. Sudman. 2007. Habitat attributes and population size of Texas kangaroo rats on an intensely grazed pasture in Wichita County, Texas. Texas Journal of Science 59:11-22.

Goetze, J. R., A. D. Nelson, D. Breed, P. D. Sudman, M. A. Nelson, AND E. WATSON. 2015. Texas kangaroo rat (Dipodomys elator) surveys in Copper Breaks State Park and surrounding areas in Hardeman County, Texas. Texas Journal of Science 67:39-48.

Goetze, J. R., A. D. Nelson, And L. L. Choate. 2016. Comparison of pasturelands containing Texas kangaroo rat (Dipodomys elator) burrows to adjacent roadsides in Wichita County, Texas, with comments on road usage by D. elator. Pp. 225-231, in Contributions in natural history: a memorial volume in honor of Clyde Jones (Manning, R. W., ed.). Special Publications, Museum of Texas Tech University 65:225-231.

Holt, S. D. S. 2018. Reinterpreting the 1882 bison population collapse. Rangelands 40:106-114. 
Jones, C., M. A. Bogan, And L. M. Mount. 1988. Status of the Texas kangaroo rat (Dipodomys elator). Texas Journal of Science 40:249-258.

LewIS, G. F. 1970. Comparative ecology and physiology of Dipodomys elator and Dipodomys ordii. M.S. thesis, Midwestern University. Wichita Falls, U.S.A.

Mares, M. A., J. K. Braun, R. M. Barquez, and M. M. Díaz. 2000. Two new genera and species of halophytic desert mammals from isolated salt flats in Argentina. Occasional Papers, Museum of Texas Tech University 203:1-27.

Martin, R. E. 2002. Status and long term survival estimates for the Texas kangaroo rat, Dipodomys elator. Unpublished final report prepared for Texas Parks and Wildlife Department. Austin, U.S.A.

Martin, R. E., ANd K. G. Matocha. 1972. Distributional status of the kangaroo rat, Dipodomys elator. Journal of Mammalogy 53:873-877.

Martin, R. E., AND K. G. Matocha. 1991. The Texas kangaroo rat, Dipodomys elator, from Motley Co., Texas, with notes on habitat attributes. Southwestern Naturalist 36:354-356.

Merriam, C. H. 1894. Preliminary descriptions of eleven new kangaroo rats of the genera Dipodomys and Perodipus. Proceedings of the Biological Society of Washington 9:109-116.

Moss, S. P., AND P. Mehlhop-Cifelli. 1990. Status of the Texas kangaroo rat, Dipodomys elator (Heteromyidae), in Oklahoma. Southwestern Naturalist 35:356-358.

Nelson, A. D., J. R. Goetze, S. Henderson, And B. Scroggins. 2013. Status survey for the Texas Kangaroo Rat (Dipodomys elator). Unpublished final report prepared for Texas Parks and Wildlife Department, Austin, Texas, Project 131, Endangered and Threatened Species Conservation Program.

Nelson, A. D., J. R. Goetze, E. Watson, And M. Nelson. 2009. Changes in vegetation patterns and their effect on Texas Kangaroo rats (Dipodomys elator). Texas Journal of Science 61:119-130.

Nelson, A. D., J. R. Goetze, S. Henderson, and B. Scoggings. 2013. Status survey for the Texas kangaroo rat (Dipodomys elator). Unpublished final report prepared for Texas Parks and Wildlife Department. Austin, U.S.A.

Oklahoma Department of Wildlife Conservation. 2016. Oklahoma Comprehensive Wildlife Conservation Strategy: A Strategic Plan for Oklahoma's Rare and Declining Wildlife. Oklahoma Department of Wildlife Conservation. Oklahoma City, U.S.A.

PACKARD, R. L., AND F. W. Judd. 1968. Comments on some mammals from western Texas. Journal of Mammalogy 49:535-538.

PaCKard, R. L., AND J. D. Roberts. 1973. Observations on the behavior of the Texas kangaroo rat, Dipodomys elator Merriam. Mammalia 37:680-682.

Prau, R. S., J. R. Goetze, R. E. Martin, K. G. Matocha, and A. D. Nelson. 2019. Spatial and temporal genetic diversity of the Texas kangaroo rat, Dipdomys elator (Rodentia: Heteromyidae). Journal of Mammalogy 100:1169-1181.

RoberTs, J. D., AND R. L. PACKARD. 1973. Comments on movements, home range and ecology of the Texas kangaroo rat, Dipodomys elator Merriam. Journal of Mammalogy 54:957-962.

Savage, C. Chattanooga. 2018. The Encyclopedia of Oklahoma History and Culture, https://www.okhistory.org/publications/enc/entry.php?entry=CH009 (accessed May 30, 2018).

Sikes, R. S., W. L. Gannon, AND the animal Care and use committee of the American Society of Mammalogists. 2011. Guidelines of the
American Society of Mammalogists for the use of wild mammals in research. Journal of Mammalogy 92:235-253.

Sikes, R. S., AND the animal Care and use committee of the American Society Of Mammalogists. 2016. Guidelines of the American Society of Mammalogists for the use of wild mammals in research and education. Journal of Mammalogy 97:663-688.

Slabach, B., and J. J. Krupa. 2018. Range expansion of Sigmodon hispidus (Hispid Cotton Rat) into coal surface-mines in southeastern Kentucky. Southeastern Naturalist 17:N84-N89.

Stangl, F. B., And T. S. Schafer. 1990. Report on the current status of the Texas kangaroo rat, Dipdomys elator, in northcentral Texas. Unpublished final report prepared for Texas Parks and Wildlife Department. Austin, U.S.A.

Stangl, F. B., T. S. Schafer, J. R. Goetze, and W. Pinchak. 1992. Opportunistic use of modified and disturbed habitat by the Texas kangaroo rat (Dipodomys elator). Texas Journal of Science 44:25-35.

Stangl, F. B., JR., M. M. Shipley, J. R. Goetze, and C. Jones. 2005. Comments on the predator-prey relationship of the Texas kangaroo rat (Dipodomys elator) and barn owl (Tyto alba). American Midland Naturalist 153:135-141.

StASey, W. C. 2005. An evaluation of Texas kangaroo rat (Dipodomys elator): biological habits and population estimation. M.S. thesis, Tarleton State University. Stephenville, U.S.A.

Stasey, W. C., J. R. Goetze, P. D. Sudman, And A. D. Nelson. 2010. Differential use of grazed and ungrazed plots by Dipodomys elator (Mammalia: Heteromyidae) in north central Texas. Texas Journal of Science 62:3-14.

Sykes, L., L. Santini, A. Etard, And T. Newbold. 2019. Effects of rarity form on species' responses to land use. Conservation Biology 34:688-696.

Texas. Secretary of State. 1977. Texas Register 2:2597 (texashistory.unt.edu/ark:/67531/metapth252983/: accessed May 18, 2018), University of North Texas Libraries, The Portal to Texas History, texashistory.unt.edu; crediting UNT Libraries Government Documents Department.

Texas. Secretary of State. 1985. Texas Register 10:5001 (texashistory.unt.edu/ark:/67531/metapth243747/: accessed May 18, 2018), University of North Texas Libraries, The Portal to Texas History, texashistory.unt.edu; crediting UNT Libraries Government Documents Department.

Texas. Secretary of State. 1987. Texas Register 12:465 (texashistory.unt.edu/ark:/67531/metapth243854/: accessed May 18, 2018), University of North Texas Libraries, The Portal to Texas History, texashistory.unt.edu; crediting UNT Libraries Government Documents Department.

U.S. Fish and Wildifife Service. 2011. Endangered and threatened wildlife and plants; 90-day finding on a petition to list the Texas kangaroo rat as endangered and threatened. Federal Register 76:12683-12690.

Wahle, R., E. Roth, and P. Horner. 2018. Dipodomys elator. The IUCN Red List of Threatened Species 2018: e.T6675A22227507. http://dx.doi.org/10.2305/IUCN. UK.2018-1.RLTS.T6675A22227507.en. Downloaded on 18 November 2019.

Webster, W. D., AND J. K. Jones, JR. 1985. Nongeographic variation, reproduction, and demography in the Texas kangaroo rat, Dipodomys elator (Rodentia, Heteromyidae). Texas Journal of Science 37:51-61. 
Wildearth Guardians. 2010. Petition to list the Texas kangaroo rat (Dipodomys elator) under the U.S. Endangered Species Act. WildEarth Guardians. Denver, U.S.A.

WrnN, J. 2011. Roosevelt Visit, April 1905. Tillman County Chronicles, Blogspot https://tillmancountychronicles. blogspot.com/2011/03/roosevelt-visit-april-1905.html.

Associated editor: Lisa and Robert Bradley

Submitted: February 1, 2021; Reviewed: March 5, 2021;

Accepted:March 29, 2021; Published on line:May 28, 2021. 